\section{A PLASMID OF THE SISOMICIN PRODUCER MICROMONOSPORA INYOENSIS}

\author{
Yair Parag and Maria Elisabeth Goedeke \\ Department of Genetics, The Hebrew University, \\ Jerusalem, Israel
}

(Received for publication April 23, 1984)

Species of the actinomycete Micromonospora are the producers of the commercially important group of aminoglycoside antibiotics, the gentamicins: Micromonospora echinospora and $M$. purpurea produce gentamicin $\mathrm{C}$ and $M$. inyoensis produces sisomicin ${ }^{1 \sim)}$. In view of the importance of these organisms it would be useful to attempt to find plasmids in order to establish breeding systems for these organisms. During our preliminary genetic study of $M$. inyoensis we isolated a large plasmid. The yield of plasmid DNA was very low and most subisolates did not show plasmids at all. A similar but more extreme situation had been observed in Streptomyces griseus NRRL 3851, a cephamycin producer, in which it had been impossible to detect the plasmid DNA in spite of many efforts ${ }^{5}$. It has been found recently that it is possible to induce the excision of a chromosomally integrated plasmid to become a free multicopy plasmid in $S$. griseus $^{\mathrm{e})}$. Therefore our approach was to attempt the induction of free plasmid in a plasmid deficient subisolate of $M$. inyoensis. The successful efforts reported here concerning the appearance of a plasmid following UV irradiation gives a support to the view that such an induction may be a general method for obtaining plasmids in industrial strains. In our specific case it enabled the physical analysis of the plasmid and should facilitate its development eventually as a vector for gene cloning in Micromonospora.

\section{Experimental and Results}

Batches $(20 \mathrm{ml})$ of overnight shake cultures (CM medium: glucose $10 \mathrm{~g}$, yeast extract $5 \mathrm{~g}, \mathrm{~N}-\mathrm{Z}$ amine $5 \mathrm{~g}, \mathrm{KH}_{2} \mathrm{PO}_{4} 2 \mathrm{~g}, \mathrm{~K}_{2} \mathrm{HPO}_{4} 4 \mathrm{~g}, \mathrm{MgSO}_{4}$. $7 \mathrm{H}_{2} \mathrm{O} 0.5 \mathrm{~g}, \mathrm{H}_{2} \mathrm{O} 1$ liter) of $M$. inyoensis M100 (a sisomicin producing strain from Schering Corp., N.J.) at $37^{\circ} \mathrm{C}$, were diluted in batches of $200 \mathrm{ml}$
$\mathrm{CM}$ medium and incubated for 1 2 days at $37^{\circ} \mathrm{C}$. Sucrose and glycine were added to final concentrations of $25 \%$ and $0.5 \%$ respectively and the cultures were incubated further for 1 hour. Plasmid DNA was isolated by a scaledup modification ${ }^{8)}$ of the BIRNBOIM and DoLY procedure $^{7)}$. The plasmid DNA was separated by $\mathrm{CsCl}$-ethidium bromide gradient centrifugation and analyzed by agarose gel electrophoresis $(0.7 \%$ agarose gel in TEA buffer $)$ and restriction endonuclease digestion as described by LABAN and $\mathrm{COHEN}^{\mathrm{s})}$.

UV Irradiation: The overnight cultures (log phase) were irradiated in Petri dishes $(0.5 \mathrm{~cm}$

Fig. 1. Agarose-gel electrophoresis of DNA preparations of $M$. inyoensis M100.

1, 3; No UV treatment. 2, 4; After UV treatment. 3, 4; DNA cleaved with Pst I endonuclease.

a; plasmid pIM1 cccDNA. b; chromosomal DNA. c, d; Pst I fragments of pIM1.

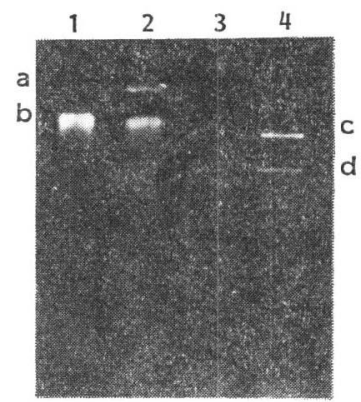

Fig. 2. Gel-electrophoresis analysis of restriction fragments of pIM1 DNA.

a; Cla I, b; Cla I+Pst I, c; Pst I, d; Cla I+ Hind III, e; Hind III, f; Pst $\mathrm{I}+$ Hind III, g, h; size references: g, SCP2*, cleaved with Eco RI, $31 \mathrm{~Kb}^{11)}$; h, four Bam HI fragments of SCP2*, $15.9 \mathrm{~Kb}, 8.5$ $\mathrm{Kb}, 4.5 \mathrm{~Kb}, 2.2 \mathrm{~Kb}^{11)}$.

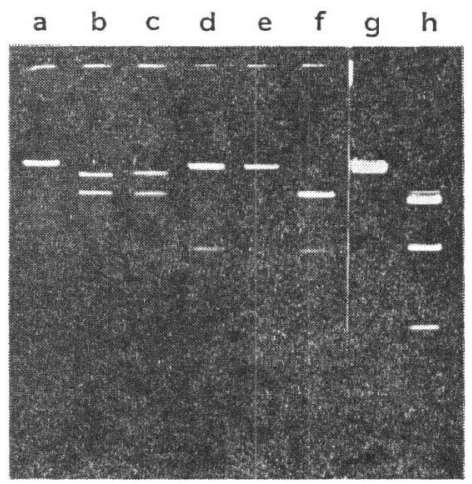


Fig. 3. Restriction endonuclease map of plasmid pIM1.

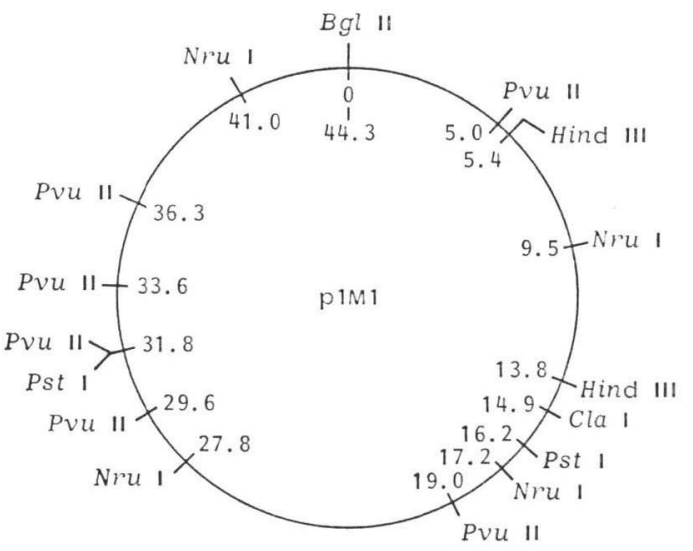

Fig. 4. Electron microscope pictures of plasmids of M. inyoensis.

A; pIM1, relaxed ccc DNA (length indicates $43 \sim$ $43.5 \mathrm{~Kb}$ ).

$\mathrm{B}$; One of the small plasmids with internal reference (length indicates $16.5 \mathrm{~Kb}$ )

$\mathrm{C}$; The smaller plasmid (length indicates $10.3 \mathrm{~Kb}$ ).

$\mathrm{R}$; reference: $\phi \mathrm{X} 174 \mathrm{DNA}=1.77 \mu \mathrm{m}=5.386 \mathrm{~Kb}$, refs 12,13 .

Bar represents $0.5 \mu \mathrm{m}$.

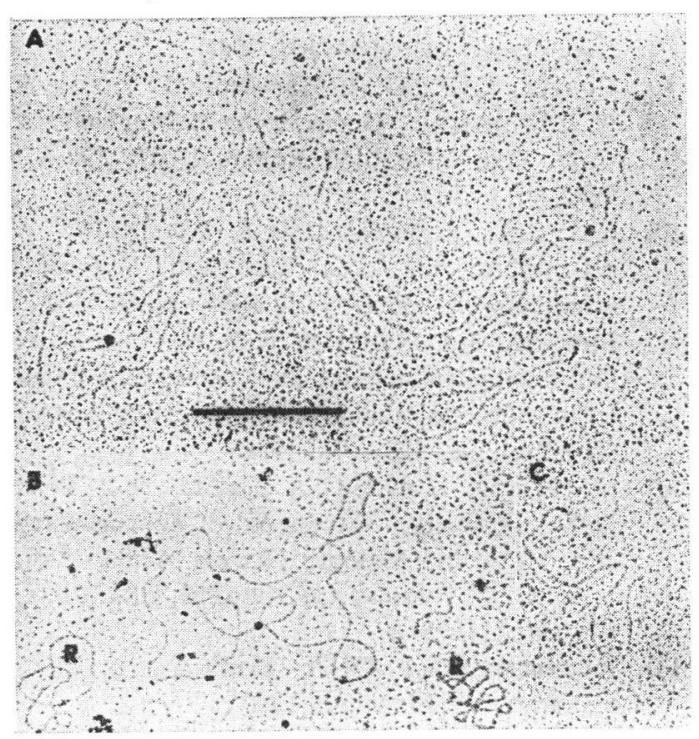

depth), 30 seconds, $60 \mathrm{~cm}$ from a GE Germicidal lamp, 30 Watts, 1,000 ergs $/ \mathrm{mm}^{2}$ before the transfer to the flasks with $200 \mathrm{ml} \mathrm{CM}$ medium.

$M$. inyoensis M100 was found to contain extrachromosomal DNA in covalently closed form following $\mathrm{CsCl}$-ethidium bromide centri- fugation and by agarose-gel electrophoresis separation. On agarose-gel electrophoresis this DNA migrated more slowly than the chromosomal DNA (Fig. 1), indicating a large molecular weight ( $c a .44 \mathrm{~Kb}$ ). The size of the plasmid pIM1 was determined to be $44.3 \mathrm{~Kb}$ by agarose gel electrophoresis analysis of the whole plasmid as well as its restriction endonuclease fragments (Fig. 2). The positions of the cleavage sites of six restriction endonucleases, as determined by single and double digestion (Fig. 2), on the physical map of the plasmid pIM1 is presented in Fig. 3. The plasmid also has $8 K p n \mathrm{I}$ and 12 Bam HI sites. It has two unique sites for the restriction endonucleases Cla I and $B g l$ II (Fig. 3).

Electron microscopic observations revealed supercoiled and open circle molecules of $43 \sim$ $46 \mathrm{~Kb}$ (Fig. 4A); in some of the preparations of $\mathrm{CsCl}$ gradients smaller plasmids $(10.3 \mathrm{~Kb}$ and $16.5 \mathrm{~Kb}$ ) were also observed (Fig. 4B, C). The nature of these small plasmids and their relation to pIM1 is not clear.

In preliminary experiments the yields of plasmid DNA were very low; moreover, plasmid DNA could not be recovered from most subisolates. A subisolate of $M$. inyoensis $\mathrm{M} 100$, which repeatedly failed to yield plasmid DNA, was selected for testing the effect of UV irradiation. Following a high dose-1,000 ergs $/ \mathrm{mm}^{2}$ - of UV irradiation of shake cultures at the log phase, plasmid DNA was easily detected in $\mathrm{CsCl}$ ethidium bromide gradients and in electrophoresis separations. In 10 repeats, a discernible amount of plasmid DNA was always observed following the UV induction, but no plasmid DNA was observed in the uninduced controls (Fig. 1). A two month old induced culture continued to yield plasmid DNA without further induction. The plasmid that had been isolated in the preliminary experiments without UV treatment was identical with pIM1: its size was $44 \mathrm{~Kb}$ and it had the same two Pst I and 12 Bam HI fragments.

\section{Discussion}

In the last several years gene cloning techniques have been applied to this industrially important group of organisms ${ }^{9)}$. However, sometimes the host range of a vector developed for one 
organism does not include another organism, chosen for study because of its industrial importance. Endogenous plasmids may be prefered for development into cloning vectors for such microorganisms, but sometimes industrial strains do not seem to carry endogenous free plasmids, as in the cases of $M$. inyoensis and S. griseus. It is being suggested that the induction of the appearance of plasmid DNA in an apparently plasmid deficient actinomycete, as reported here and for $S$. griseus ${ }^{6)}$, may be a general method for the isolation of resident plasmids in actinomycetes. The mechanism of the effect of UV irradiation and the source of the reappearing plasmid are not yet clear. In S. griseus the excision of a free plasmid out of the chromosome can be induced ${ }^{\text {()) }}$; a similar interpretation was suggested to the UV induction of plasmid in the archaebacterium Sulfobolus acidocaldarius ${ }^{10)}$. Alternatively, it is possible that the UV induces the increase in copy number of the resident plasmid from a preinduced very low (and thus undetectable) copy number plasmid. The plasmid pIM1 with its unique sites for inserting selective markers can now be used for attempting transformation and eventually gene cloning in Micromonospora.

\section{Acknowledgments}

The authors are grateful to Prof. A. COHEN for discussions and suggestions, to Ms. M. BRoIT for the electron micrographs, and to Dr. M. Weinstein, Schering Corp. Bloomfield, N. J., for the sisomicin producing strain, M. inyoensis M100. This work was supported in part by a grant from Schering Corp., Bloomfield, N. J., and Bayer AG, Leverkusen, Germany; and by a grant from the National Council for Research and Development, Israel, and the G.S.F., Munchen, Germany.

\section{References}

1) Weinstein, M. J.; E. M. Lueederman, E. M. Oden \& G. H. Wagman: Gentamicin, a new broad-spectrum antibiotic complex. Antimicrob. Agents Chemother. -1963: 1 7, 1964

2) Rinehart, K. L., Jr. \& R. M. Stroshane: Biosynthesis of aminocyclitol antibiotics. J. Antibiotics 29: 319 353, 1976

3) Marget, W. \& G. Gruenwaldt, Eds.: Sisomicin, a new aminoglycoside antibiotic. Infection. 4, Suppl. 4: S283 S513, 1976

4) Weinstein, M. J.; G. H. Wagman \& J. A. WeITZ: Discovery and isolation of sisomicin. Infection 4, Suppl. 4: S285 S288, 1976

5) Parag, Y.: Mapping and plasmid control in Streptomyces griseus, producer of cephamycin. In Genetics of Industrial Microorganisms. Ed., O.K. Sebek \& A.I. LASkin, pp. 258 262, Amer. Soc. Microbiol., Washington DC, 1979

6) Cohen, A.; D. Bar-Nir, M. E. Goedeke \& Y. PARAG: The integrated and free states of Streptomyces griseus plasmid pSG1. Plasmid, in press

7) Birnboim, H. C. \& J. Doly: A rapid alkaline extraction procedure for screening recombinant plasmid DNA. Nucl. Acids Res. 7: 1513 1523,1979

8) LABAN, A. \& A. COHEN: Inter and intra plasmidic recombination in Escherichia coli K-12. Mol. Gen. Genet. 184: 200 207, 1981

9) Chater, K. F.; D. A. Hopwood, T. Kieser \& C. J. Thompson: Gene cloning in Streptomyces. Curr. Top. Microbiol. Immunol. 97: 69 95, 1982

10) Yeats, S.; P. MCWilliam \& W. Zillig: A plasmid in the archaebacterium Sulfobolus acidocaldarius. Embo J. 1: 1035 1038, 1982

11) Bibв, M.; J. L. Schottel \& S. N. Cohen: A DNA cloning system for interspecies gene transfer in antibiotic-producing Streptomyces. Nature (London) 284: 526 531, 1980

12) MacHattie, L. A. \& C. A. Thomas, Jr.: Viral DNA molecules. Handbook of Biochemistry and Molecular Biology, Nucleic Acids. Vol. I, Ed. G. D. FASMAN, pp. 549 559, CRC Press, Cleveland, 1975

13) Kornberg, A.: DNA Synthesis. p. 724, Freeman, San Francisco, 1980 